\title{
Study of various characters and major practices used in cultivation of cotton varieties in Maharashtra
}

V.A. VIKHE, N.S. DALE, R.B. UMBARKAR, V.N. ANAP AND G.B. LABADE

Received : 14.06.2014; Revised : 12.08.2014; Accepted : 25.08.2014

\begin{abstract}
The present investigation was carried out in 10 villages of Aurangabad and Ahmednagar districsts of Maharashtra state. The total of 12 farmers practising cotton cropping system from each village were selected accordingly. In this way 120 farmers were taken as respondents. The data were collected through personal interview method. Four species of cotton is grown in Maharashtra namely, Gossypium hirsutum, Garboreum, G. barbandense and G. herbaceum. Out of these, G. hirsutum occupies largest area covering about 52-53 per cent of cotton. Out of total studied varieties, the hybrid varieties such as Gold 50 gave more yield compared to other varieties. Almost all the hybrid varieties were good to be cultivated. The climatic conditions of Maharashtra are also good for getting good cotton yield. Successful cultivation of hybrid cotton in Maharashtra has brought a new hope of hybrid cotton research and development in India as well spread of hybrid cotton would help to increase global cotton production.
\end{abstract}

KEY WORDS : Cotton, Varieties, Cultivation practices

How to cite this paper : Vikhe, V.A., Dale, N.S., Umbarkar, R.B., Anap, V.N. and Labade, G.B. (2014). Study of various characters and major practices used in cultivation of cotton varieties in Maharashtra. Internat. J. Com. \& Bus. Manage, 7(2) : 295-299.

\section{MEMBERS OF THE RESEARCH FORUM}

Correspondence to:

V.A. VIKHE, College of Agriculture Business Management, Loni, AHMEDNAGAR (M.S.) INDIA

Email: vijayvikhe11@gmail.com

Authors' affiliations:

N.S. DALE AND R.B. UMBARKAR, College of Agriculture Biotechnology, Loni, AHMEDNAGAR (M.S.) INDIA

V.N. ANAP AND G.B. LABADE, College of Agriculture, Loni, AHMEDNAGAR (M.S.) INDIA 